\title{
Achieving sustainable low flow using hydropower reservoir for ecological water management in Glomma River Norway
}

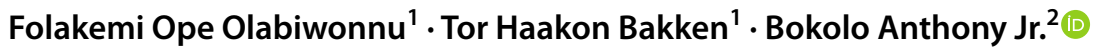

Received: 3 September 2021 / Accepted: 9 February 2022 / Published online: 28 February 2022

(c) The Author(s) 2022

\begin{abstract}
Generally, low flow in rivers occur as a result of extended period of dryness which is likely attributed to drought. Drought is a natural occurrence as an outcome of reduction in precipitation in a region for a long time. Hence, low flow is a growing concern as there are possibilities of more reduced flows in rivers. However, reservoirs can be utilized to mitigate negative effects on the supply of water in dry periods and supply water for other purposes. This study aims at verifying how the low flow condition of Glomma River in Norway has been progressively sustained by hydropower reservoirs. Water Evaluation and Planning Systems (WEAP) software was used for modelling the natural streamflow condition of Glomma River, which is the longest river in Norway, using two unregulated sub-basins within the Glomma catchment. Findings from this study presents that the period between January and March are critical periods in Glomma River. Results show that the values the annual minimum low flow gotten from the three gauges suggest the flow after regulation has increased significantly as opposed to before regulation. The daily average flow is simulated by WEAP to be an average of $100 \mathrm{~m}^{3} / \mathrm{s}$ during the low flow periods and an average discharge of $350 \mathrm{~m}^{3} / \mathrm{s}$ during the summer. However, the result indicates that the flow in the summer has reduced by $80 \%$ in majority of the years. In addition, Nash Sutcliffe efficiency (NSE) for the two sub basins used for this study was 0.9 and 0.76 , respectively. Also, the calculation of the coefficient of determination $\left(R^{2}\right)$ resulted in 0.85 and 0.78 respectively for the two sub basins. In particular, findings from this study presents evidence on the low flow condition in Glomma River prior to its regulation and how the regulation has sustained the flow.
\end{abstract}

Keywords Low flow $\cdot$ Pre-regulation $\cdot$ Hydropower reservoir $\cdot$ WEAP $\cdot$ Glomma River · Norway

$\begin{array}{ll}\text { Abbreviations } \\ \text { WEAP } & \text { Water evaluation and planning systems } \\ \text { IHA } & \text { International Hydropower Association } \\ \text { IRENA } & \text { The International Renewable Energy Agency } \\ \text { NVE } & \text { Norwegian Water Resources and Energy } \\ & \begin{array}{l}\text { Directorate } \\ \text { TNC }\end{array} \\ \end{array}$

Folakemi Ope Olabiwonnu olabiwonnufolakemi@gmail.com

Bokolo Anthony Jr. anthony.j.bokolo@ntnu.no

Tor Haakon Bakken tor.h.bakken@ntnu.no

1 Department of Civil and Environmental Engineering, Norwegian University of Science and Technology, S.P. Andersens veg 5, 7491 Trondheim, Norway

2 Department of Computer Science, Norwegian University of Science and Technology, NTNU, NO-7491 Trondheim, Norway

\section{PEST Parameter estimation tool \\ SEI Stockholm Environment Institute \\ NSE Nash Sutcliffe efficiency}

\section{Introduction}

Over several centuries the need for water has increased for more purposes than sanitation. As time went by, it began to be seen as an economic good as it can be used for hydropower production (Barbier 2019). But with the increasing need for water comes different challenges arising from day to day of which one of them is the changing climate (Dai 2011). Drought is seen as one of the most damaging weather-related challenges as regards economic cost (Van Loon and Laaha 2015). Even though drought occurs naturally, due to climate change, its effect on hydrological processes has become more intense (Mukherjee et al. 2018). Moreover, drought is a temporary dry period and can be termed as a disaster which 
occurs periodically. It has environmental, social, and economic effect in any region where it occurs (Wen et al. 2011; Kumar 2020). Thus, the damaging effect it has on the eco-system cannot be over emphasized (Van Loon and Laaha 2015) and consequently, low flow periods can be experienced in rivers (Vicente-Serrano et al. 2014).

As regarded to morphology of the valleys and the type of river (braided, meander, anastosomado) the behavior of the Glomma River with respect to its flow and use as energy hydroelectric. The Glomma River is regulated and have regulation capabilities of 16 percent and have experienced fewer floods in the 1900s as compared to 1800s. The size of the floods has also reduced. This is because the regulation reservoirs, which were built within the 1900s for hydroelectric production have had a moderating impact on floods. The regulation reservoirs in the Glomma River Basin can retain approximately 16 percent of all the water that the river basin brings to the sea annually. Corresponding results from other regulated river basins in Southern and Eastern Norway are 30-55 percent. River basins with higher percentage of reservoirs hardly experience damage throughout spring floods (NVE 2022). It meanders southward through the Østerdal valley, sometimes breaking up into braids and then flows westward into Lake Øyeren, hence forming Europe's largest inland delta as recommended in the literature (Britannica 2011). It is $460.7 \mathrm{~km}$ long and historically known in Norway for being a log-floating river. Equally, it is maximized for hydropower production. Its hydroelectric dams power the paper and cardboard mills at Rena town. Hence, it has several run-of-river power plants situated on it (Berge et al. 2008).

The main problem to be addressed in this study points to the fact that drought has been a major issue across the world and Norway is not exempted. Nevertheless, Norway is a country that exploits its water by regulating it so it can be used for multiple purposes, one of which is hydropower (Young et al. 2011). Hence, hydropower is the country's primary source of power supply (NVE 2020b). This can however have a positive or a negative effect on the biodiversity around the river. Accordingly, this study aims to address the following research questions.

RQ1. What is the effect of reservoirs on low flow periods in Glomma River?

RQ2. Is the water released during low flow period sufficient to achieve sustainable low flow period?

Therefore, the objective of this current study intends to investigate the effect of hydropower on the flow condition in Glomma River in Norway especially with regards to low flow. Glomma River is selected as a case study in this research since it the longest and largest river in Norway.

\section{Literature review}

\section{Hydropower for energy production in Norway}

Progressive environmental awareness over several years has led to heightened usage of renewable sources for generating electricity (Zarfl et al. 2015; Olabiwonnu et al. 2021). In fact, renewable energy has become a generally desired source of generating electricity for its economic and environmental benefits (Fan et al. 2020; Igwe et al. 2020). Hence, hydropower which is one of the renewable energy sources currently making waves in the energy sector has been improved over time as more research is being carried out (Fasol 2002; Keller and Hartmann 2019). Hydropower exploits water which can either be free-flowing or dammed water to generate electricity thus, it can be classified as either run-of-river or reservoir projects (IPCC 2011). In addition, energy generation via the use of hydropower project produces a reliable energy which is also affordable (Fasol et al. 2002; Fan et al. 2020). According to International hydropower association, there are three main types of schemes:

- Run-of-river hydropower: this entails the use of freeflowing water to generate electricity with little or no storage (IHA 2020).

- Storage hydropower: in this system a reservoir is used to store water which can be used in periods of high demand for electricity (IRENA 2020).

- Pumped hydropower: in this type of system water can be recycled between a lower and upper reservoir for use in providing peak load supply and recycled during periods of low demand (IHA 2020).

Renewable energy is deeply promoted in Norway as the country primarily generates electricity via hydropower production by maximizing its mountainous and steep falls environment. Furthermore, Norway presently has a total number of 1667 of power plants and an approximate yearly production of $136 \mathrm{TWh}$. However, according to NVE (2020a) the estimated production by the end of 2020 will be $153 \mathrm{TWh}$.

\section{Background of low flow in rivers}

It is generally believed that low flow is the flow that occurs at dry periods of the year alone. However, it can also be considered as a general reduction in the flow regime of the river which can be attributed to changes in the natural flow regime of a river (Smakhtin 2001). Yet, one of the actions that can result in a higher or lower than anticipated 
is regulation of flows in rivers. Though, according to Stromberg et al. (2007) it is seen that river regulation in fact increases flow rate during low flow periods and can also be useful in dampening floods. Hence, researchers such as Smakhtin (2001) argued that low flow can be sustained by additional release of water during these periods.

Ordinarily, the lowest flows occur due to snow storage during the winter months while low flow events which occur during the summer are a result of precipitation deficit and high evaporation (Tallaksen 2000; Galvez et al. 2019). Aside from this, there are transition regions which can experience low flow anytime, be it summer or winter (Hisdal et al. 2001), hence, low flow can be experienced in any of these two seasons (Hisdal et al. 2001; Tallaksen 2000). However, the occurrence of severe low flow considering future increasing demand for water will have a critical impact on the environment. An analysis of historical time series of data therefore provides the necessary information needed to model low flow and understand how to mitigate it (Tallaksen 2000; Shahraki 2019).

In cold countries such as Norway low flow is experienced more during the winter due to the storage of precipitation as snow. Therefore, river regulation can either help to sustain low flow during these periods or worsen it depending on how the reservoir is managed and operated (Smakhtin 2001; Huokuna et al. 2020). Norway precipitation is experienced as snow during the winter months, and this can go on for three to five months. During this period, runoff is highly reduced and demand for electricity is at its peak (Thaulow et al. 2016). Specifically, depending on counties within Norway seasonal streamflow fluctuates. For example, it was discovered that the western part of Norway experiences higher precipitation and has steep falls in comparison to the eastern side which has low precipitation and wider valleys (L'AbéeLund and Villar 2017).

Nevertheless, periods of low flow can be very distressing for aquatic life in rivers, as it can result in increased water temperature and interrupt seasonal fish migration (Keefer et al. 2009). According to Righter et al. (1996); Rolls et al. (2012), hydrological attributes that affect the biodiversity around a river are changes in the magnitude of the flow, the time span of the low flow conditions, the frequency of low flow in a river, and the timing of the low flow event in relation to season. The hydrological attributes of low flow in rivers is illustrated as seen in Fig. 1.

Figure 1 depicts hydrological attributes of low flow in rivers adapted based on findings from the literature (Rolls et al. 2012). Figure 1 shows that hydrological attributes of low flow in rivers mainly comprises of timing, magnitude, duration, rate of change, and frequency. Similarly, the hydrological indices which act as Indicators of hydrological alterations were developed by The Nature Conservancy (TNC) and described by Richter et al. (1996) to examine hydrological alterations in the environment. Hence, the indices can be adopted and used as to assess streamflow regime as suggested by Olden and Poff (2003). Presently, Hydrological indices or parameters are increasingly applied in research for describing and assessing the different streamflow regimes (Olden and Poff 2003) due to hydrologic alterations which causes notable changes in hydrologic attributes (Kannan et al. 2018; Tunji et al. 2020). Hydrological alteration can affect the discharge of water which can in turn increase the length of dry periods in a river (Dinpashoh et al. 2019). As any variation to runoff inevitably affects the biodiversity in the river, according to Richter et al. (1996) there are several important streamflow characteristics that can be used in assessing riverine biotic and abiotic eco system integrity. Some of the streamflow characteristics are the annual and seasonal variability, timing of extremes, seasonal pattern of flow, water temperature, dissolved oxygen level and many more.

\section{Related works}

Prior studies have contributed to explore river regulation in relation to low flow. A few of these studies are reviewed in this section. Among these studies Huokuna et al. (2020) researched on the effect of ice in reservoirs and regulated rivers. Based on a case study the authors identified that the hydrograph for regulated monthly mean discharge has modified low flow in comparison with hydrograph of unregulated flow. The authors focused on presenting some key areas about ice in regulated river systems, mainly related to reservoirs and dams. Their study was aligned to ice with respect to dam failure, hydropower generation, and dam removal. Another current study by Tunji et al. (2020) studied the development of a water surface area storage volume relationship for Uganda's Namodope Reservoir. The authors provided a methods of measuring reservoir sedimentation which is not time-consuming, laborious, less expensive, and not weather dependent. Also, geospatial technology was utilized to carry out reservoir capacity survey in afast, frequently, and economically method to compute the reservoirs' volume and area.

Additionally, Ždankus et al. (2019) studied the protection of river downstream of a hydropower plant. The authors aimed to assess the potentials to prevent riverbed erosion downstream of hydropower plant, towards protecting fish population and enhance the navigation states and development of effective measures. Accordingly, the author proposed a new method for protecting the riverbed from erosion and safeguarding the water fauna downstream of a hydropower plant. Also, Barton et al. (2016) employed a Bayesian belief network to analyze significant adverse impact of the European Union (EU) Water Framework Directive on hydropower production in Norway. The authors discussed 


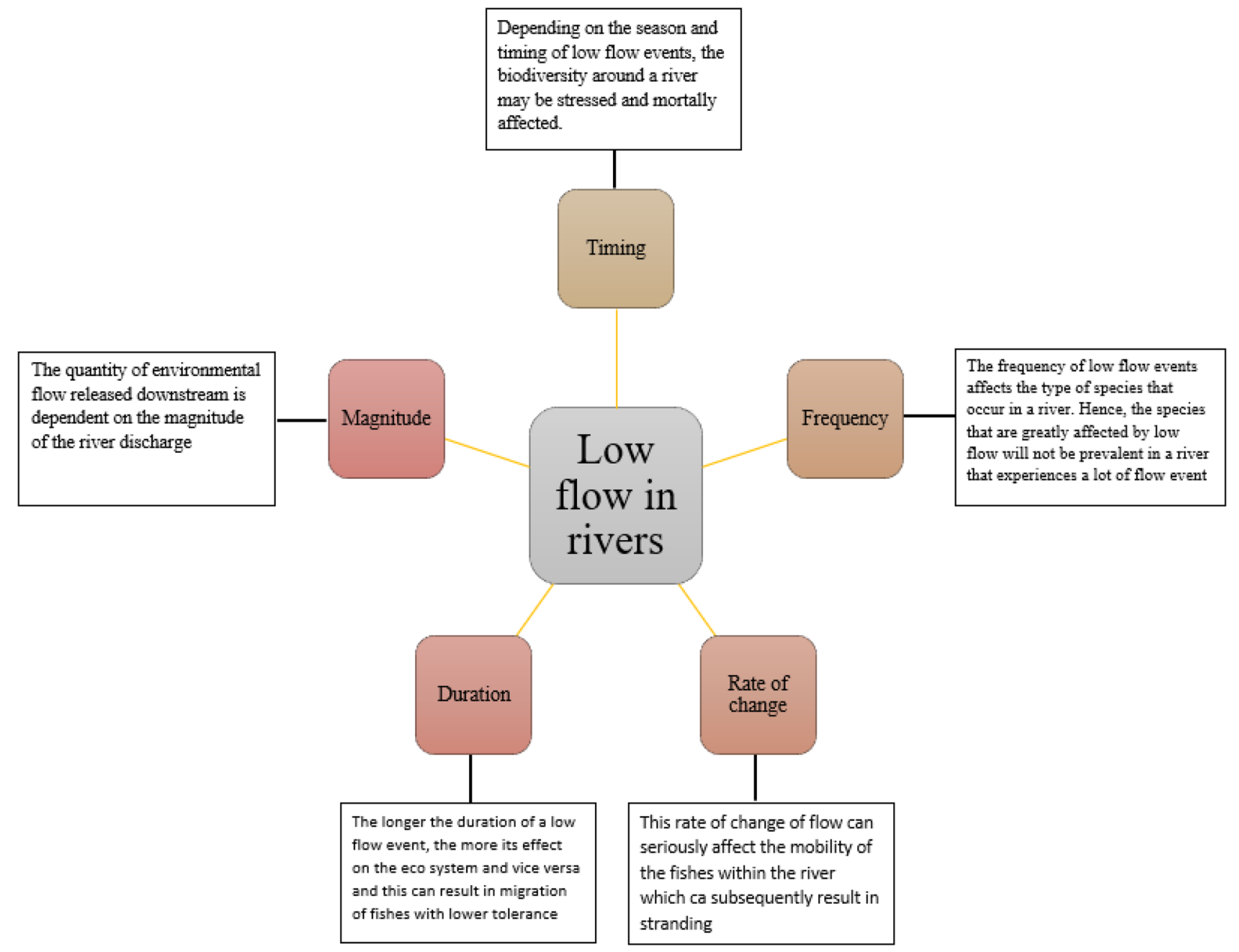

Fig. 1 Hydrological attributes of low flow in rivers adapted from (Rolls et al. 2012)

the significance of further local and regional evaluation of all available parameters to achieve better environmental potential in Norwegian water courses.

Furthermore, Guo et al. (2012) investigated the effects of the three gorges dam on Yangtze River flow and river interaction with Poyang Lake, China. Findings from their study signifies that that due to impoundment by the three Gorges dams. The results also suggest that there was reduced flow hence the low flow period was not improved but after October release of water was observed due to hydropower generation. This helped to increase the outflow in the rivers during the low flow seasons. The results also highlighted the needs for employing strategies to balance the impacts of the dams on flood control and water resources as well as their ecological and societal consequences within the Poyang Lake basin. Rolls et al. (2012) explored mechanistic effects of low-flow hydrology on riverine ecosystems ecological principles and consequences of alteration. The authors argued that natural periods of low flow can be sustained via flow regulation.
Zhang et al. (2012) examined the Three-Gorges Dam made the Poyang Lake wetlands wetter and drier. The authors stated that irrespective of the adverse effects of the dam construction the discharge released during the low flow periods are higher. Stromberg et al. (2007) explored the importance of low-flow and high-flow characteristics to restoration of riparian vegetation along rivers in arid south-western United States. Findings from their study revealed that reservoirs help to increase flow in dry periods and also dampen floods.

McMahon and Finlayson (2003) investigated droughts and anti-droughts based on the low flow hydrology of Australian rivers. Findings from the authors indicated that in a regulated river it was noticed that the periods of low flow have higher discharges after regulation and the streamflow during the summer is reduced. Thus, flow regulation reduces the severity of low flow. Smakhtin (2001) researched on low flow hydrology based on a review. Findings from their study showed that river regulation can be used to modify low flow conditions in river if the operation and maintenance of the 
river is properly carried out. Rørslett et al. (1989) investigated the effects of hydropower development on aquatic macrophytes in Norwegian rivers present state based on existing knowledge and evidence from case studies. The study aimed to examine how river regulation can increase discharge during the winter and reduce the summer discharge considerably in Norway.

Based on the reviewed 11 studies, it is evidence that reservoirs have helped in considerably increasing discharge during low flow periods. For instance, Norway is experiencing high demand for electricity during winter months, and this is also when runoff is extremely low (Thaulow et al. 2016). But the ability to harness hydropower as an energy source for generating electricity in Norway can also be impactful on the low flow period. Hence, the hydropower reservoirs can also be used to help reduce the effect of the dry period on the biodiversity in the river by the release of water to the downstream reaches to sustain periods of low flow (Isaak et al. 2012). However, based on the reviewed 11 studies there are fewer studies that have explored how to achieve sustainable low flow using hydropower reservoir for ecological water management.

Therefore, this current study adds to the body of knowledge by examining how sustainable low flow using hydropower reservoir for ecological water management can be achieved in Glomma River Norway. Also, this study aims to examine how the effect of reservoirs on low flow periods in Glomma River can be modelled and to verify the impact of the reservoir on the seasonal flow periods in Glomma River.

\section{Methods}

This study employs WEAP for modeling Glomma River to examine the impact of reservoirs on low flow periods. Glomma River vassdraget which is a part of a river in Southeastern Norway, was selected to be the study catchment. Glomma River was selected for this study due to its expansive use by hydropower operators.

Figure 2 depicts the location of Glomma River within Norway. Glomma River catchment area is depicted in Fig. 2 and it is $20305 \mathrm{~km}^{2}$ with a specific discharge of $15.2 \mathrm{l} / \mathrm{s}^{*} \mathrm{~km}^{2}$. It is a river that is maximized for hydropower production as there are several power plants that make use of the water from this river. According to Berge et al. (2008), there are 26 hydropower reservoirs on Glomma River and 57 stations linked to these reservoirs (Gooch et al. 2010). In addition, Glomma River is a conducive river for fish population. Hence, up to 24 fish species flourishes in this river and due to the reservoirs on it a fish passage had to be constructed to allow the free passage of the fishes around the river even after river regulation (Linløkken 1993; Hesthagen and Sandlund 2004).

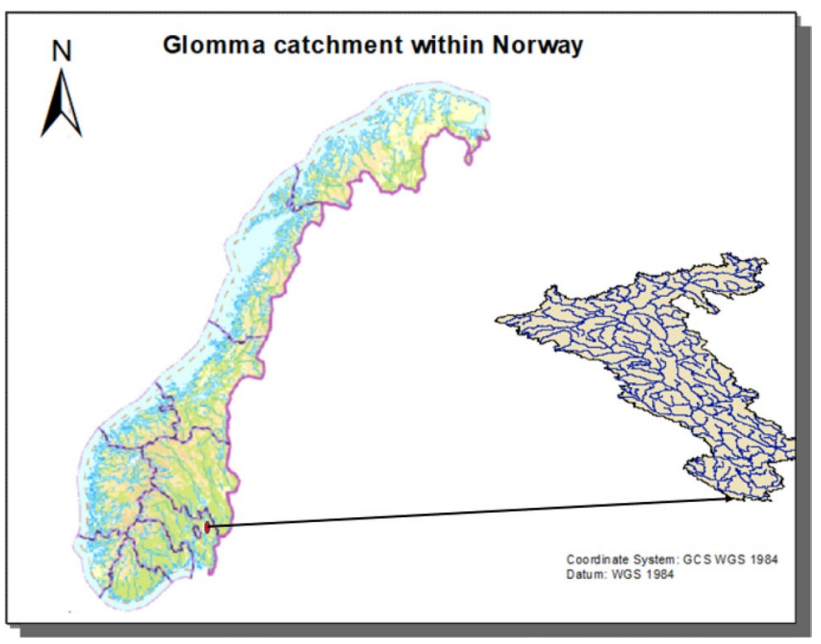

Fig. 2 The location of Glomma River within Norway

\section{Overview of WEAP}

Water Evaluation and Planning System (WEAP) is an initiative of the Stockholm Environment Institute (WEAP. org 2020). It is a modelling software that can be used to simulate different water demand and supply amongst other processes, and it can be used to assess water resource planning and management issues (Arranz and McCartney 2007). According to Yates et al. (2009), WEAP21 can describe the water-related infrastructure and institutional arrangements of a region in a comprehensive, outcome-neutral, model-based planning environment that can identify strategies and help evaluate freshwater ecosystem services.

In addition, WEAP can be utilized for simulating and analyzing different processes and scenarios involving water planning and management of river basin (Arranz and McCartney 2007; Yates et al. 2005). Therefore, as described by Yates et al. (2005) WEAP operates by the principle of water supply versus water demand, and it understands precipitation that comes into the basin as the water supply while this supply lessens over time depending on the pressing water demand.

Moreover, WEAP is very user-friendly. Its interface allows simulation time step to be set as desired by the researcher (Arranz and McCartney 2007; Yates et al. 2005) and it is able to simulate hydrologic processes which can be made to permit assessment and management of water in a river basin (Yates et al. 2005). Previous studies in Water resources management study have made use of WEAP for river simulation and scenario analysis (Mugatsia 2010). Hence, WEAP can be used to study the water processes before and after hydrologic alterations and is employed as the modeling tool in this study to examine the impact of reservoirs on low flow periods in Glomma River and assess how has the water subsequently sustained the fish population. 


\section{Modelling of the unregulated flow in Glomma River}

As this study involves modelling of the unregulated flow as well as the present regulated river flow to properly assess the low flow condition of the river. Hydrological data which include precipitation, temperature, and runoff data were retrieved from Norwegian Meteorological Institute database. The period studied was chosen to be from 2009 till 2019 due to availability of time series of data, and good data quality. Hence, the data were retrieved by relying on information gotten from the gauges in the river. In addition, shapefiles for the river network with tributaries and precipitation fields were retrieved from the Norwegian Water Resources and Energy Directorate Map Catalog in WGS84 coordinate system for use in WEAP software.

Afterwards, two unregulated sub-basins were calibrated and simulated with WEAP. This helped to calibrate the Glomma catchment, to simulate the pre-regulation river flow condition of Glomma River. Hence, the two sub-basins were represented as sub-basin 1 and sub-basin 2, and they were selected to represent the upstream and downstream region of Glomma River as shown in Fig. 3. Sub-basin 1 has a catchment area of $110.6 \mathrm{~km}^{2}$ and specific discharge of $11.4 \mathrm{l} / \mathrm{s} * \mathrm{~km}^{2}$ while sub-basin 2 has an area of $1367.9 \mathrm{~km}^{2}$ in comparison and a specific discharge of $11.41 / \mathrm{s}^{*} \mathrm{~km}^{2}$.

For the sub-basins, selected parameters in WEAP had to be calibrated. Hence, with the use of Parameter Estimation Tool (PEST) which the Stockholm Environment Institute (SEI) has linked to WEAP software. An automatic calibration was carried out with emphasis on Land use and Climatic data.

Afterwards, the performance of the two sub-basins were assessed using Nash Sutcliffe Efficiency (NSE) and coefficient of determination $\left(R^{2}\right)$. The equations used are respectively represented below as Eq. (1) and (2).

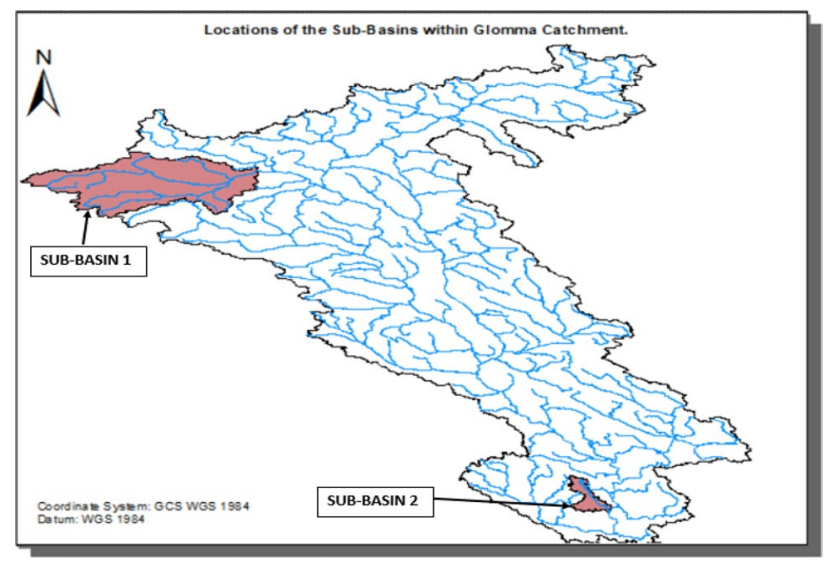

Fig. 3 Locations of the sub-basins used in calibrating the unregulated flow in Glomma River
$\mathrm{NSE}=1-\frac{\sum_{t=1}^{T}\left(Q_{m}^{t}-Q_{o}^{t}\right)^{2}}{\sum_{t=1}^{T}\left(Q_{o}^{t}-\overline{Q_{o}}\right)^{2}}$

where $\overline{Q_{o}}$ is the mean of observed discharge, $Q_{m}$ is the modelled discharge and $Q_{o}^{t}$ is the observed discharge at time t.

$R^{2}=\left(\frac{\sum_{i=1}^{n}\left(O_{i}-\bar{O}\right)\left(S_{i}-\bar{S}\right)}{\sqrt{\sum_{i=1}^{n}\left(O_{i}-\bar{O}\right)} \sqrt{\sum_{i=1}^{n}\left(S_{i}-\bar{S}\right)}}\right)^{2}$

where $O_{i}$ is the observed time series of data, $S_{i}$ is the modelled data, $\bar{O}$ is the mean of observed discharge, $\bar{S}$ is the mean of modelled data.

Since the two models had a good fit between their observed and simulated runoff and with the result gotten from NSE and the $R^{2}$, they were considered to be good enough to use to model the entire Glomma catchment. Hence, the two sub-basins were used in calibrating the upstream and downstream part of the Glomma River. Therefore, the natural flow condition of the Glomma catchment before its regulation was modelled and simulated. It should be noted that this was carried out to properly assess how the low flow has changed over the years and in WEAP software, Rainfall Runoff (soil moisture) method was used chosen as the catchment simulation method in this study.

\section{Modelling of the regulated flow in Glomma River}

To assess the effect that the reservoirs on Glomma River has had on the flow especially the low flow condition. Three gauges situated at strategic points in the Glomma River were chosen from the Norwegian Water Resources and Energy Directorate (NVE) measuring stations database. Thus, the three gauges used are Noorfoss gauge, Atnasjoen gauge, and Glomstadfoss gauge. Their discharge between year 2009 and 2019 were retrieved and used to generate a new simulation result on WEAP software.

Specifically, to interpret the results simulated from WEAP software, monthly averages were derived from the pre regulation and post regulation discharge. Afterwards, these results were processed using excel software to show the low flow occurrence in the river for both winter and summer. The winter months (December, January, and February) and the summer months (June, July, and August) were separated and then the annual minimum discharge experienced during the summer and the annual minimum discharge experienced during the winter months were extracted to be graphically represented as the measure of low flow in Glomma River. Also, from the data inputted into WEAP software, the potential evapotranspiration and the actual 
Table 1 Result of the statistical analysis of the unregulated sub-basins

\begin{tabular}{lll}
\hline Model performance evaluators & Sub-basin 1 & Sub-basin 2 \\
\hline NSE & 0.90 & 0.76 \\
$R^{2}$ & 0.85 & 0.78 \\
Climatic factors & & \\
$\quad$ Elevation range (m.a.s.l) & $618-1850$ & $150-550$ \\
Latitude $\left({ }^{\circ}\right)$ & 62 & 60 \\
\hline
\end{tabular}

evapotranspiration rate of Glomma River was simulated, and its result duly presented.

\section{Results}

The results showing the model performance are presented based on Nash Sutcliffe efficiency (NSE) and coefficient of determination $\left(R^{2}\right)$, where the optimum value is 1 . Therefore, for the calibration to be accepted the result must be as close to 1 as possible. Hence, as illustrated in Table 1 results from the statistical analysis of the two unregulated sub-basins suggest that the models are both acceptable as they are within the required range.
Result of the pre-regulation runoff in Glomma River

The results of the simulation of the pre-regulation flow in Glomma River using WEAP are presented as daily average and annual total discharge in Figs. 4 and 5, respectively.

\section{Result of Glomma River post regulation}

The result of the simulation was also computed for the three gauges Noorfoss gauge, Atnasjoen gauge, and Glomstadfoss gauge to show the post regulation effect of reservoirs stationed on Glomma River as illustrated in Fig. 6.

\section{Result of the low flow in relation to critical periods}

To properly show the effect of regulation on low flow periods, the annual minimum low flow simulated using WEAP for all three gauges is presented in Fig. 7.

\section{Result showing the evapotranspiration rate in Glomma River.}

The average monthly evapotranspiration value as simulated by WEAP software in Glomma River is represented in the Table 2.
Fig. 4 Result for the condition of the daily average flow before the regulation of Glomma River
The simulated natural daily average runoff in Glomma river (Before regulation)

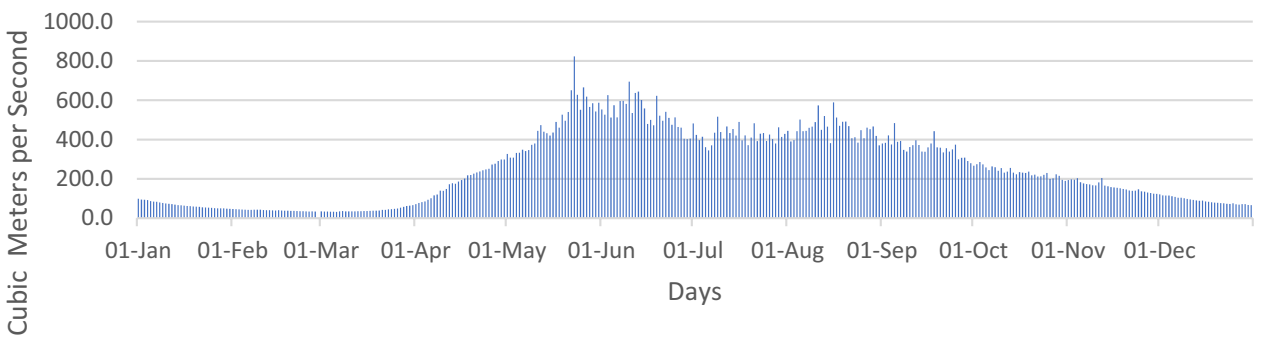
annual total runoff in Glomma River before its regulation
Annual total runoff from Glomma river (Before regulation)

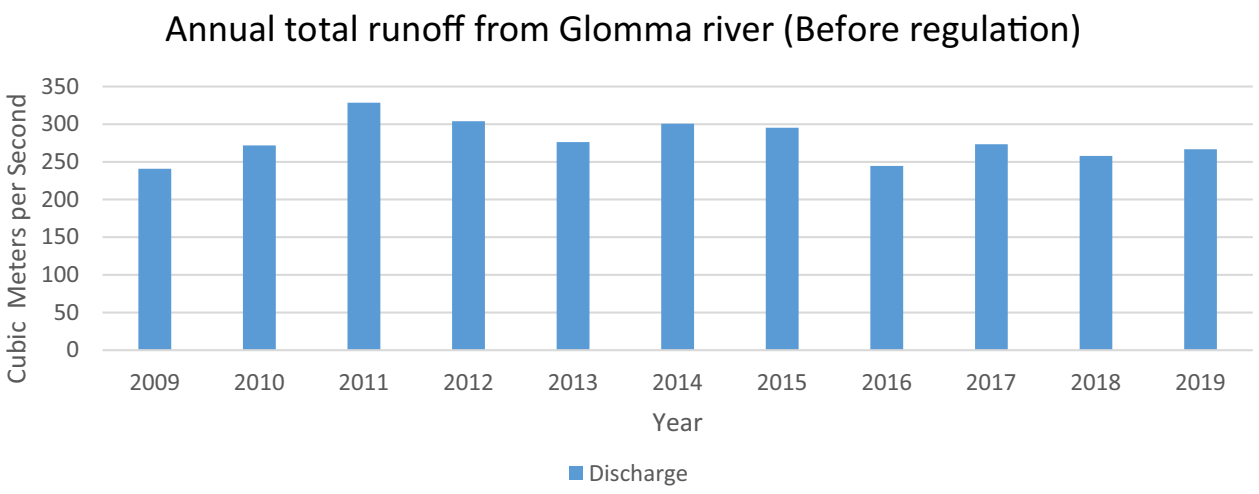


Fig. 6 The hydrograph showing the pre and post regulation result of Glomma River
Hydrograph of simulated and observed flow at Glomma river

1200

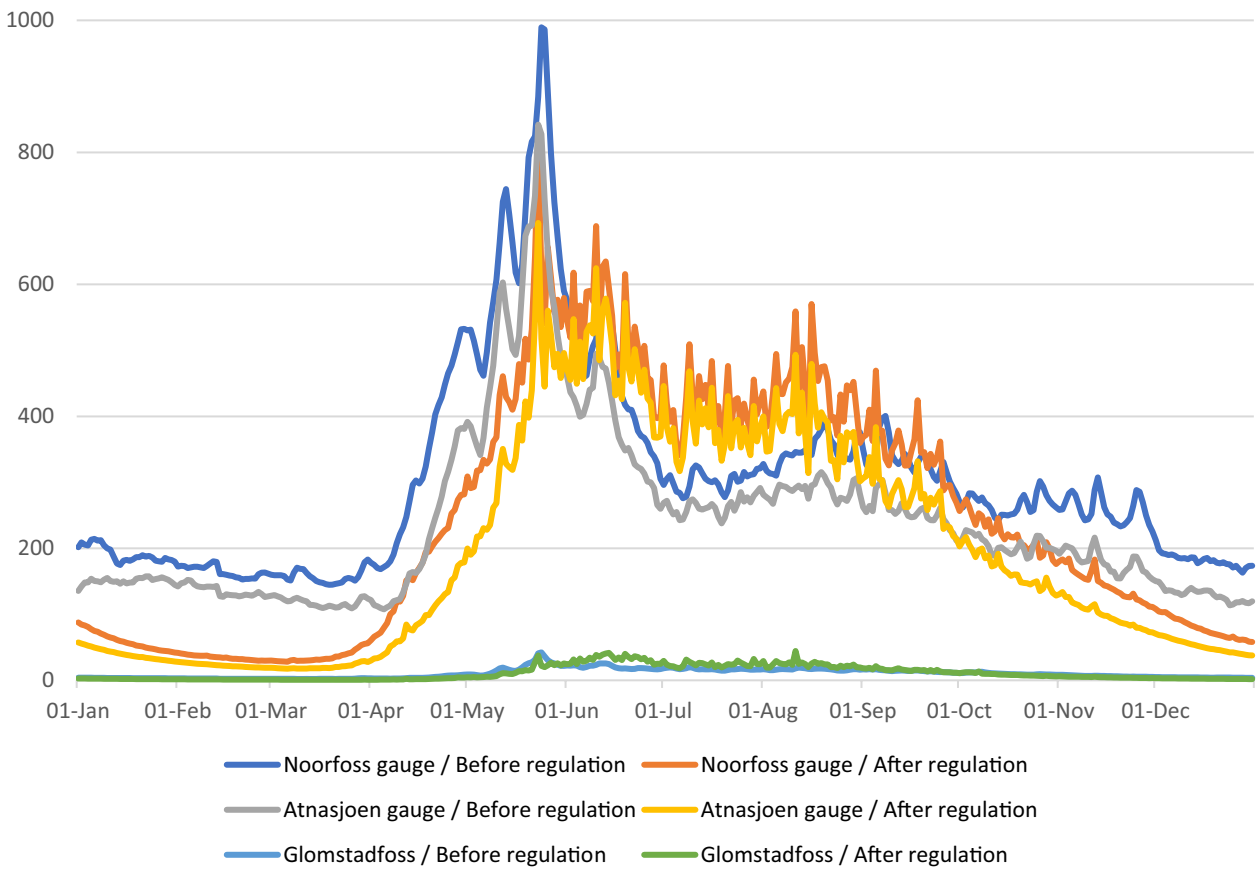

\section{Discussion and implications of study}

Figure 4 shows the pre regulation flow simulated for Glomma River. As Glomma River is extensively used for hydropower, the daily average flow is simulated by WEAP to be an average of $100 \mathrm{~m}^{3} / \mathrm{s}$ during the low flow periods and an average discharge of $350 \mathrm{~m}^{3} / \mathrm{s}$ during the summer. This may also be as a result of snow melt during the spring. Also, from the model, Fig. 5 which presents the annual total runoff shows a slight fluctuation and gradual decrease in discharge.

In addition, Fig. 6 depicts the results from the simulated hydrograph which represents the natural runoff in Glomma River as simulated using the three gauges Noorfoss, Atnasjoen, and Glomstadfoss gauges before regulation. This hydrograph properly captured the low flow within the catchment. However, the simulated flow showed a reduced peak before regulation as opposed to higher peak. This may be due to the model simulating a much higher melting than what occurs in reality or due to a deflection that may have occurred as a result of the averaging of daily data in all the years.

To properly show the effect of regulation in low flow periods, the annual minimum flow during summer and winter period for both pre and post regulation period were presented for all the gauges in Fig. 7. For the Atnasjoen Gauge, Fig. 7 showed that during the Winter, the minimum flow has doubled by almost $50 \%$ as compared to how it was before the regulation. However, during the Summer, the result is more varied. In some of the years, the minimum flow remained the same after river regulation while for most of the years, the minimum flow has reduced.

Besides, findings from Fig. 7 established that in both Glomstadfoss and Noorfoss Gauges the runoff during the winter has tripled as compared to what it used to be before regulation. This finding can be useful particularly to the biotas around the Glomma River. Besides, this finding may be specifically helpful in sustaining the fish population, as it helps to reduce the stranding of fishes in isolated pool. However, the result indicates that the flow in the summer has reduced by $80 \%$ in majority of the years and has an increase of around $20 \mathrm{~m}^{3} / \mathrm{s}$ which is not so much. Hence, after regulation the peaks have reduced during the summer. This is a positive impact that helps the downstream reach as the reservoir has indeed helped to capture the spring flood.

In addition to this, the evapotranspiration rate at Glomma River was measured using WEAP for both the actual and potential evapotranspiration as represented in Table 2. The result however showed that for all the years simulated, the potential evapotranspiration was higher than the actual evapotranspiration rate. This can be important in estimating crop water need in the event of future water use for irrigation. Findings from this study is similar to result from previous study as detailed by Tena et al. (2019). 


\section{Annual minimum flow in Glomma river.}

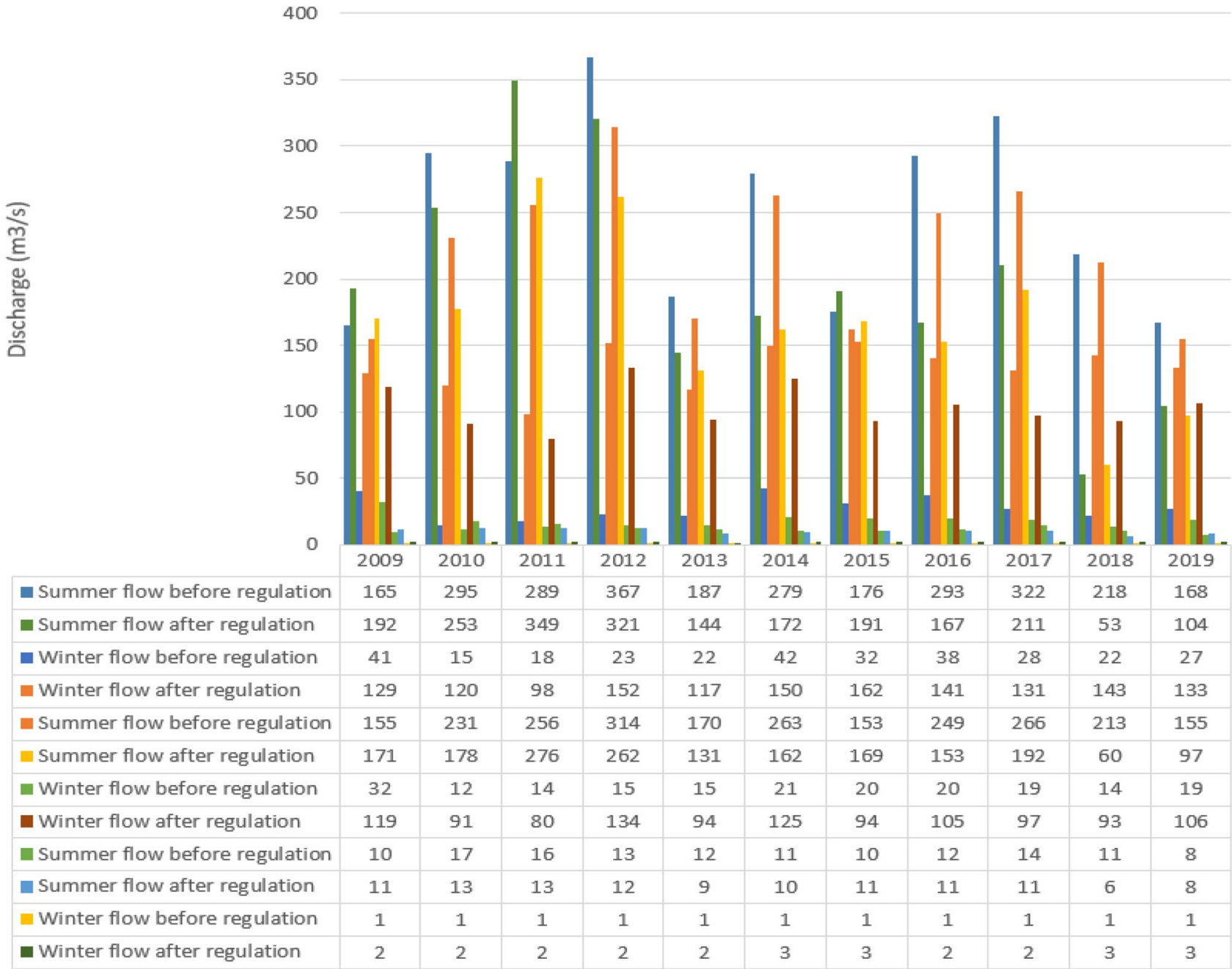

Fig. 7 Annual minimum low flow gotten from the three gauges studied in relation to Glomma River

Table 2 shows the Evapotranspiration rate in Glomma River as simulated by WEAP

\begin{tabular}{llllllllllll}
\hline Years & 2009 & 2010 & 2011 & 2012 & 2013 & 2014 & 2015 & 2016 & 2017 & 2018 & 2019 \\
\hline $\begin{array}{l}\text { Actual } \\
\text { Evapotran- } \\
\text { spiration } \\
(\mathrm{mm})\end{array}$ & 236 & 198 & 232 & 210 & 191 & 207 & 205 & 195 & 191 & 182 & 195 \\
$\begin{array}{l}\text { Potential } \\
\text { Evapotran- } \\
\text { spiration } \\
(\mathrm{mm})\end{array}$ & 752 & 512 & 552 & 516 & 538 & 559 & 532 & 545 & 527 & 569 & 543 \\
\hline
\end{tabular}

In summary, the results (see "Overview of WEAP", "Modelling of the unregulated flow in Glomma River", "Modelling of the regulated flow in Glomma River") show that after the flow regulation, the water released downstream during the low flow periods have increased significantly in Gauges Noorfoss and Glomstadfoss but not as much in
Atnasjoen Gauge. This is notably important for the aquatic life in Glomma and especially for the fish population, as there is need for preservation of their species and population. Since Brown trout and graylings are well known to occupy Glomma River (Heggenes et al. 1996), the release of more water (more runoff) during the periods of low flow will be 
useful to the brown trout and graylings. As periods of low flow can affect the survival rate of graylings, particularly young graylings. Also, the spring flood during the summer has been successfully captured by the reservoir in comparison to how it was before the regulation. Hence, the river regulation has helped to sustain the low flow period and thereby the eco system around the river.

Although this research has explored and assessed the role that hydropower reservoirs play in sustaining ecologically water management specifically in Glomma River Norway it does have some limitations. In this study, the role of ground water to the precipitation and temperature data was not considered. Also, this study did not incorporate hydropower plants and their influence due to system priority and energy demand.

\section{Conclusion, limitations, and future works}

Over the decades the need for water has increased and the availability of water is seen as an economic good as it can be used for hydropower production. Hence, the need for efficient water management as well as for improvement of water policies is needed for conservation of the eco-system. But with the increasing need for water comes different challenges arising from day to day of which one of them is the changing climate. Drought is seen as one of the most damaging weather-related challenges as regards economic cost. Even though drought occurs naturally due to climate change its effect on hydrological processes has become more intense. Usually, low flow in rivers occur as a result of an extended period of dryness which is likely attributed to drought. The advantage of this current study as compared to prior studies is that this research study examined how to achieve sustainable low flow using hydropower reservoir for ecological water management in Glomma River Norway which has not been well investigated in the literature. The novelty of this study relates to the fact that the effect of river regulation on low flow condition was assessed using Glomma River in Norway as case study.

Furthermore, the natural streamflow in Glomma River was simulated by calibrating two sub-basins with historical dataset, using WEAP software. Afterwards, streamflow data were retrieved from three (3) gauges. Hence, the annual river runoff was simulated. Results suggest that under present climate and with Glomma River being heavily regulated, the period between January and March are critical periods even though they are within dry season. In addition, the critical periods of low flow in Norway were taken into consideration, and the annual minimum flow during the summer and the winter was calculated. The results were presented in maps and graphs. Using this method, the pre regulation flow could easily be compared to the post regulation flow to effectively assess how hydropower has sustained periods of low flow in the study area. Future works will investigate the effect of the timing of the streamflow as studied by Dinpashoh et al. (2019) and the economic impact of climate change on hydropower reservoirs. In addition, the reservoir operating rules can be incorporated to better simulate the effect of drought on low flow condition and the economic consequences of the low flow condition and climate change can be considered.

Author contributions FOO contributed to drafting the manuscript. FOO also contributed to carrying out the literature review, conducting the experiment and modelling. TAB contributed to providing links to get the data required and checking the results and presentation of the manuscript. BAJ contributed to carrying out the literature review and ensuring the implications and significance of the study is presented.

Funding Open access funding provided by NTNU Norwegian University of Science and Technology (incl St. Olavs Hospital - Trondheim University Hospital). This study did not receive any funding.

Availability of data and material All data used for this study are included within the manuscript.

\section{Declarations}

Conflict of interest Not applicable.

Ethical approval Not applicable.

Consent to participate Not applicable.

Consent to publish Not applicable.

Open Access This article is licensed under a Creative Commons Attribution 4.0 International License, which permits use, sharing, adaptation, distribution and reproduction in any medium or format, as long as you give appropriate credit to the original author(s) and the source, provide a link to the Creative Commons licence, and indicate if changes were made. The images or other third party material in this article are included in the article's Creative Commons licence, unless indicated otherwise in a credit line to the material. If material is not included in the article's Creative Commons licence and your intended use is not permitted by statutory regulation or exceeds the permitted use, you will need to obtain permission directly from the copyright holder. To view a copy of this licence, visit http://creativecommons.org/licenses/by/4.0/.

\section{References}

Arranz R, McCartney MP (2007) Application of the water evaluation and planning (WEAP) model to assess future water demands and resources in the olifants catchment, South Africa, vol 116. IWMI, Colombo

Barbier E (2019) The water paradox: overcoming the global crisis in water management. Yale University Press, Yale

Barton DN, Bakken TH, Madsen AL (2016) Using a Bayesian belief network to diagnose significant adverse effect of the EU Water 
Framework Directive on hydropower production in Norway. J Appl Water Eng Res 4(1):11-24

Berge D, Nhung DK, Hoang PTT, Barton D, Nesheim I (2008) The use of environmental flows in IWRM, with reference to the hydropower regulated Glomma River (Norway) and Sesan River (Vietnam and Cambodia) (Striver WP 8). Norwegian Institute for Water Research, Oslo

Britannica T (2011) Editors of Encyclopaedia. Glomma. Encyclopedia Britannica. https://www.britannica.com/place/Glomma. Accessed 28 January 2022.

Dai A (2011) Drought under global warming: a review. Wiley Interdis Rev Clim Change 2(1):45-65

Dinpashoh Y, Singh VP, Biazar SM, Kavehkar S (2019) Impact of climate change on streamflow timing (case study: Guilan Province). Theoret Appl Climatol 138(1):65-76

Fan JL, Hu JW, Zhang X, Kong LS, Li F, Mi Z (2020) Impacts of climate change on hydropower generation in China. Math Comput Simul 167:4-18

Fasol KH (2002) A short history of hydropower control. IEEE Control Syst Mag 22(4):68-76

Galvez V, Rojas R, Bennison G, Prats C, Claro E (2019) Collaborate or perish: water resources management under contentious water use in a semiarid basin. Int J River Basin Manag 18:421

Gooch GD, Rieu-Clarke A, Stalnacke P (2010) Integrating water resources management. Iwa Publishing, London

Guo H, Hu Q, Zhang Q, Feng S (2012) Effects of the three gorges dam on Yangtze river flow and river interaction with Poyang Lake, China: 2003-2008. J Hydrol 416:19-27

Heggenes J, Saltveit SJ, Lingaas O (1996) Predicting fish habitat use to changes in water flow: modelling criticalminimum flows for Atlantic salmon, Salmo salar, and brown trout, S. trutta regulated rivers. Res Appl 12:331-344

Hesthagen T, Sandlund OT (2004) Fish distribution in a mountain area in south-eastern Norway: human introductions overrule natural immigration. In the Atna River: studies in an alpine-boreal watershed. Springer, Dordrecht, pp 49-59

Hisdal H, Tallaksen LM (2000) Assessment of the regional impact of droughts in Europe. Drought event definition technical report to the ARIDE project (6).

Hisdal H, Stahl K, Tallaksen LM, Demuth S (2001) Have streamflow droughts in Europe become more severe or frequent? Int J Climatol 21(3):317-333

Huokuna M, Morris M, Beltaos S, Burrell BC (2020) Ice in reservoirs and regulated rivers. Int J River Basin Manag. https://doi.org/10. 1080/15715124.2020.1719120

Igwe O, Ifediegwu SI, Onwuka OS (2020) Determining the occurrence of potential groundwater zones using integrated hydro-geomorphic parameters, GIS and remote sensing in Enugu State, Southeastern, Nigeria. Sustain Water Resour Manag 6:1-14

IHA (2020). International Hydropower Association 2020 Hydropower Status Report. Retrieved 26 October 2020.

IPCC (2011) IPCC special report on renewable energy sources and climate change mitigation. IPCC, Geneva

IRENA (2020). International Renewable Energy Agency https://www. irena.org/hydropower. Last assessed 24 October 2020

Isaak DJ, Wollrab S, Horan D, Chandler G (2012) Climate change effects on stream and river temperatures across the northwest US from 1980-2009 and implications for salmonid fishes. Clim Change 113(2):499-524

Kannan N, Anandhi A, Jeong J (2018) Estimation of stream health using flow-based indices. Hydrology 5(1):20

Keefer ML, Moser ML, Boggs CT, Daigle WR, Peery CA (2009) Effects of body size and river environment on the upstream migration of adult Pacific lampreys. North Am J Fish Manag 29(5):1214-1224
Keller N, Hartmann T (2019) OECD water governance principles on the local scale-an exploration in Dutch water management. Int J River Basin Manag 18:439

Kumar DN (2020) Hydro-geochemical assessment of groundwater through statistical analysis for sustainable usage in Medchal Mandal, Hyderabad India. Sustain Water Resour Manag 6(6):1-18

L'Abée-Lund JH, Villar JO (2017) Start-stop practice in small Norwegian hydropower plants. NVE, Norway

Linløkken A (1993) Efficiency of fishways and impact of dams on the migration of grayling and brown trout in the Glomma River system, south-eastern Norway. Regul Rivers: Res Manag $8(1-2): 145-153$

Lobón-Cerviá J, Sanz N (eds) (2017) Brown trout: biology, ecology and management. Wiley, New York

McMahon TA, Finlayson BL (2003) Droughts and anti-droughts: the low flow hydrology of Australian rivers. Freshw Biol 48(7):1147-1160

Mugatsia EA (2010). Simulation and scenario analysis of water resources management in Perkerra catchment using WEAP model. Masters Thesis, Department of Civil and Structural Engineering, School of Engineering, Moi University, Kenya

Mukherjee S, Mishra A, Trenberth KE (2018) Climate change and drought: a perspective on drought indices. Curr Clim Change Rep 4(2):145-163

NVE (2020a). Hydropower. https://www.nve.no/energiforsyning/ kraftproduksjon/vannkraft/?ref=mainmenu. Last assessed 14 October 2020a

NVE (2020b) Power generation https://www.nve.no/energiforsyning/ kraftproduksjon/?ref=mainmenu. Last assessed on 15 October $2020 \mathrm{~b}$

NVE (2022) Norwegian water resources and energy directorate. Living with Floods. https://publikasjoner.nve.no/hydra/diverse/livin gwithfloods2000.pdf. Last assessed on 30 January 2022

Olden JD, Poff NL (2003) Redundancy and the choice of hydrologic indices for characterizing streamflow regimes. River Res Appl 19(2):101-121

Ope Olabiwonnu F, Haakon Bakken T, Anthony Jnr B (2021) The role of hydropower in renewable energy sector toward co2 emission reduction during the COVID-19 pandemic. Int J Green Energy 19(1):52-61

Richter BD, Baumgartner JV, Powell J, Braun DP (1996) A method for assessing hydrologic alteration within ecosystems. Conserv Biol 10(4):1163-1174

Rokaya P, Peters DL, Bonsal B, Wheater H, Lindenschmidt KE (2019) Modelling the effects of climate and flow regulation on ice-affected backwater staging in a large northern river. River Res Appl 35(6):587-600

Rolls RJ, Leigh C, Sheldon F (2012) Mechanistic effects of low-flow hydrology on riverine ecosystems: ecological principles and consequences of alteration. Freshw Sci 31(4):1163-1186

Rørslett B, Mjelde M, Johansen SW (1989) Effects of hydropower development on aquatic macrophytes in Norwegian rivers: present state of knowledge and some case studies. Regul Rivers: Res Manag 3(1):19-28

Savoskul OS, Chevnina EV, Perziger FI, Vasilina LY, Baburin VL, Danshin AI, Matyakubov B, Murakaev RR (2003) Water, climate, food, and environment in the Syr Darya Basin. Contribution to the project ADAPT, Adaptation strategies to changing environments. https://citeseerx.ist.psu.edu/viewdoc/download? doi $=10.1 \cdot 1.202 .3222 \&$ rep $=$ rep $1 \&$ type $=$ pdf

Shahraki AA (2019) Supplying water in hydro-drought regions with case studies in Zahedan. Sustain Water Resour Manag $5(2): 655-665$

Smakhtin VU (2001) Low flow hydrology: a review. J Hydrol 240(3-4):147-186 
Stromberg JC, Beauchamp VB, Dixon MD, Lite SJ, Paradzick C (2007) Importance of low-flow and high-flow characteristics to restoration of riparian vegetation along rivers in arid south-western United States. Freshw Biol 52(4):651-679

Tallaksen LM (2000) Streamflow drought frequency analysis. Drought and drought mitigation in Europe. Springer, Dordrecht, pp $103-117$

Tate EL, Gustard A (2000) Drought definition: a hydrological perspective. Drought and drought mitigation in Europe. Springer, Dordrecht, pp 23-48

Tena TM, Mwaanga P, Nguvulu A (2019) Hydrological Modelling and water resources assessment of Chongwe River catchment using WEAP model. Water 11(4):839

Thaulow H, Nesheim I, Barkved L (2016) Hydropower in Norway. An overview of key tools for planning, licensing, environmental impacts, and mitigation measures. NIVA, Oslo

Tunji LAQ, Sempewo JI, Mbatya W (2020) Development of a water surface area-storage capacity relationship for Namodope Reservoir, Uganda. J Appl Water Eng Res 8(3):183-193

Van Loon AF, Laaha G (2015) Hydrological drought severity explained by climate and catchment characteristics. J Hydrol 526:3-14

Vicente-Serrano SM, Lopez-Moreno JI, Beguería S, Lorenzo-Lacruz J, Sanchez-Lorenzo A, García-Ruiz JM, Coelho F (2014) Evidence of increasing drought severity caused by temperature rise in southern Europe. Environ Res Lett 9(4):044001

WEAP21 (2020). Water evaluation and planning. https://www.weap21. org/. Last assessed 24 October 2020

Wen L, Rogers K, Ling J, Saintilan N (2011) The impacts of river regulation and water diversion on the hydrological drought characteristics in the Lower Murrumbidgee River Australia. J Hydrol 405(3-4):382-391

Yates D, Sieber J, Purkey D, Huber-Lee A (2005) WEAP21-a demand-, priority-, and preference-driven water planning model: part 1: model characteristics. Water Int 30(4):487-500

Yates D, Purkey D, Sieber J, Huber-Lee A, Galbraith H, West J, Rayej M (2009) Climate driven water resources model of the Sacramento Basin, California. J Water Res Plan Manage 135(5):303-313

Young PS, Cech JJ, Thompson LC (2011) Hydropower-related pulsed-flow impacts on stream fishes: a brief review, conceptual model, knowledge gaps, and research needs. Rev Fish Biol Fish 21(4):713-731

Zarfl C, Lumsdon AE, Berlekamp J, Tydecks L, Tockner K (2015) A global boom in hydropower dam construction. Aquat Sci 77(1):161-170

Ždankus NT, Vaikasas S, Sabas G (2019) Protection of river downstream of hydropower plant. J Appl Water Eng Res 7(1):10-20

Zhang Q, Li L, Wang YG, Werner AD, Xin P, Jiang T, Barry DA (2012) Has the Three-Gorges Dam made the Poyang Lake wetlands wetter and drier? Geophys Res Lett. https://doi.org/10.1029/ 2012GL053431

Publisher's Note Springer Nature remains neutral with regard to jurisdictional claims in published maps and institutional affiliations. 